\title{
Histomorphological Spectrum of Renal Diseases: A Prospective Study for A Period of Two Years
}

\author{
Deepthi. K. N, Shilpa Karamchedu* and Apurva \\ Department of Pathology, SVS Medical college, Yenugonda, Mahabubnagar, Telangana, India
}

\begin{abstract}
Introduction: Kidneys are vital organs of the body with multiple functions like excretory, acid base balance and maintenance of blood pressure. Renal parenchyma is mostly subjected to noxious insults but is last to respond. Simple nephrectomy is done for irreversibly damaged kidney. Most common indication for nephrectomy is chronic pyelonephritis.Aim of the study is to analyze the histopathological patterns of renal lesions and to analyze age and sex distribution.
\end{abstract}

Materials and Methods: The study included a total number of 70cases, during a period of 2 years i.e., from October 2017 to September 2019.All renal biopsies and nephrectomy specimens received in pathology department, SVS Medical College, Mahabubnagar, Telangana, India were included in the study.

RESULTS: In our study, 70 cases were analyzed. Out of which majority of the lesions $(25.7 \%)$ were in the age group of $21-40$ years and showed male preponderance (68.5\%).Present study showed chronic pyelonephritisbeing the most common non-neoplastic lesion. Among malignant tumors renal cell carcinoma was most common.

Conclusion: The present study reveals various histological patterns of lesions in renal biopsies and nephrectomy specimens. Our study reveals that non-neoplastic lesions are more commonly encountered lesions.

Keywords: Chronic Pyelonephritis, Renal Cell Carcinoma,Malignant Tumor.

\section{Introduction}

Kidneys are vital organs of the body with multiple functions like excretory function, acid base balance, maintenance of salt and water metabolism and blood pressure through rennin angiotensin mechanism and hematopoiesis by producing erythropoietin. ${ }^{[1,2]}$ Renal parenchyma, though, subjected to repeated trauma or insults of noxious environment, they are last to respond. The kidneys are affected by various disease processes, some result in permanent damage leading to surgical removal of the organ i.e., nephrectomy. Indications for nephrectomy are obstructive nephropathy, hydronephrosis, chronic pyelonephritis and renovascular hypertension. ${ }^{[3]}$

Chronic pyelonephritis with hydronephrosis is the most common type of nephrectomy specimen for non-neoplastic conditions due to increased incidence of pelvi-ureteric junction obstruction by upper ureteric calculi, where as in neoplastic group, renal cell carcinoma is the most common, due to increase in the incidence in chronic smokers. ${ }^{[4,5]}$

Renal cell carcinoma is $13^{\text {th }}$ most common malignancy worldwide. In the Asian population, the incidence ranges between 1.1 and 6.0/1,00,000 population. ${ }^{[6]}$

To study the histopathological patterns of neoplastic and non-neoplastic lesions of kidney and to study the age wise and sex wise distribution of various renal lesions.

\section{Material and Methods}

The present study was prospective study for a period of two years from October 2017 to September 2019 and included all renal biopsies and nephrectomy specimens received in department of pathology, SVS Medical College, Mahabubnagar, Telangana, India.

A total of 70 cases were included in the study. Clinical details and relevant data were recorded. Gross details were noted and representative bits were processed according to standard operating protocols. Diagnosis was made on routine Hematoxylin and Eosin stained sections. Special stains like Periodic acid schiffs stain, Massons trichrome and Ziehl Nelson stain were done in required cases. Relative frequency of different lesions, age and sex distribution were analysed.

\section{Results}

The present study was a prospective study of renal lesions from october 2017 to september 2019. A total of 70 cases were included in the study, out of which most common age group affected was $3^{\text {rd }}$ to $4^{\text {th }}$ decade $\left.(\mathrm{n}=32 ; 45.72 \%)\right)$ and least affected was $1^{\text {st }}$ decade $(\mathrm{n}=1 ; 1.43 \%)($ Table 1$)$.

In the present study, there were $48(68.57 \%)$ males and $22(31.43 \%)$ females with male: female ratio of 2.2:1(Table 2). 
Among all the renal lesions, non-neoplastic lesions $(n=57$; $81.42 \%)$ were more common than the neoplastic tumors $(\mathrm{n}=13 ; 18.58 \%)$. Out of 57 cases, maximum number of non-neoplastic cases $(n=14 ; 24.30 \%)$ were found to be chronic pyelonephritis with hydronephrosis followed by membranous nephropathy $(n=10 ; 14.30 \%)$. Few cases of diffuse proliferative glomerulonephritis, benign nephrosclerosis, Lupus nephritis and Focal segmental glomerulo sclerosis were diagnosed (Table 3 ).

In this study, membranous nephropathy was most common among glomerular lesions. Chromophobe Renal

Table 1: Age wise distribution of renal lesions.

\begin{tabular}{|l|l|l|}
\hline Age group & No of cases & Percentage \\
\hline $0-10$ Years & 1 & $1.43 \%$ \\
\hline $11-20$ Years & 5 & $7.14 \%$ \\
\hline $21-30$ Years & 10 & $14.28 \%$ \\
\hline $31-40$ Years & 18 & $25.72 \%$ \\
\hline $41-50$ Years & 14 & $20.00 \%$ \\
\hline $51-61$ Years & 12 & $17.15 \%$ \\
\hline $61-70$ Years & 10 & $14.28 \%$ \\
\hline Total & 70 & $100 \%$ \\
\hline
\end{tabular}

Table 2: Sex wise distribution of renal lesions.

\begin{tabular}{|l|l|l|}
\hline Sex & No of cases & Percentage \\
\hline Male & 48 & $68.57 \%$ \\
\hline Female & 22 & $31.43 \%$ \\
\hline Total & 70 & $100 \%$ \\
\hline
\end{tabular}

Table 3: Histopathological spectrum of renal lesions.

\begin{tabular}{|l|l|l|}
\hline Lesions & No of cases & Percentage \\
\hline Diffuse proliferative glomerulonephritis & 2 & $2.85 \%$ \\
\hline Membranoproliferative glomerulonephritis & 4 & $5.72 \%$ \\
\hline Membranous nephropathy & 10 & $14.30 \%$ \\
\hline Benign nephrosclerosis & 2 & $2.85 \%$ \\
\hline Focal segmental glomerulosclerosis & 2 & $2.85 \%$ \\
\hline Lupus nephritis & 2 & $2.85 \%$ \\
\hline Diabetic nephropathy & 6 & $8.58 \%$ \\
\hline Tubulo interstitial nephritis & 4 & $5.72 \%$ \\
\hline Granulomatous pyelonephritis TB & $5.72 \%$ \\
\hline Xanthogranulomatous pyelonephritis & 4 & $5.72 \%$ \\
\hline Oncocytoma & 4 & $2.85 \%$ \\
\hline Angiomyolipoma & 2 & $2.85 \%$ \\
\hline Thyroid follicular carcinoma like RCC & $1.43 \%$ \\
\hline Chromophobe RCC & 2 & $4.29 \%$ \\
\hline Clear cell RCC & 1 & $2.85 \%$ \\
\hline Mucinous tubular RCC & 3 & $2.85 \%$ \\
\hline Renal squamous cell carcinoma & 2 & $1.43 \%$ \\
\hline Total & 2 & $100 \%$ \\
\hline
\end{tabular}

cell carcinoma was the most common malignant tumor followed by clear cell renal cell carcinoma and mucinous tubular renal cell carcinoma. Benign tumors like renal oncocytoma and angiomyolipoma were diagnosed with equal incidence $(2.85 \%)$ (Figure $1 \&$ Figure 2$)$.

\section{Discussion}

In the present study, 70 cases were analyzed. Most common age group was $3^{\text {rd }}$ to $4^{\text {th }}$ decade. This is in concordance with the studies done by Muhammad et al., and Kishore H Suryawanshi et al. ${ }^{[7,8]}$ This is variable with other studies done by Shanmuga Swamy et al and Swarnalatha Ajmera 

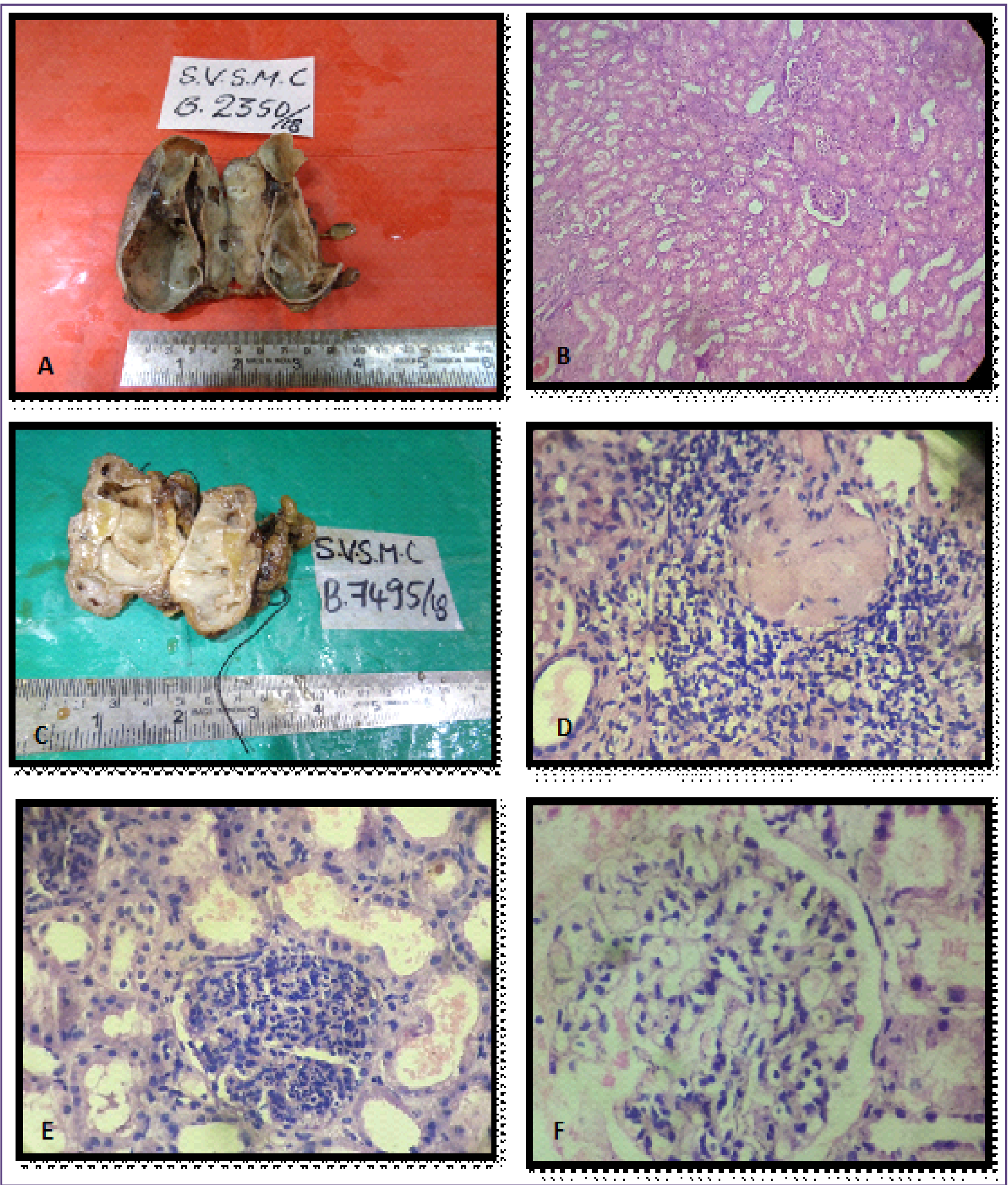

Fig. 1: A. \& B. Gross and microscopy of Chronic Pyelonephritis. C. \& D. Gross and microscopy of Tubulo interstitial nephritis. E. Diffuse proliferative Glomerulonephritis \& F. Membrano Proliferative glomerulonephritis. 

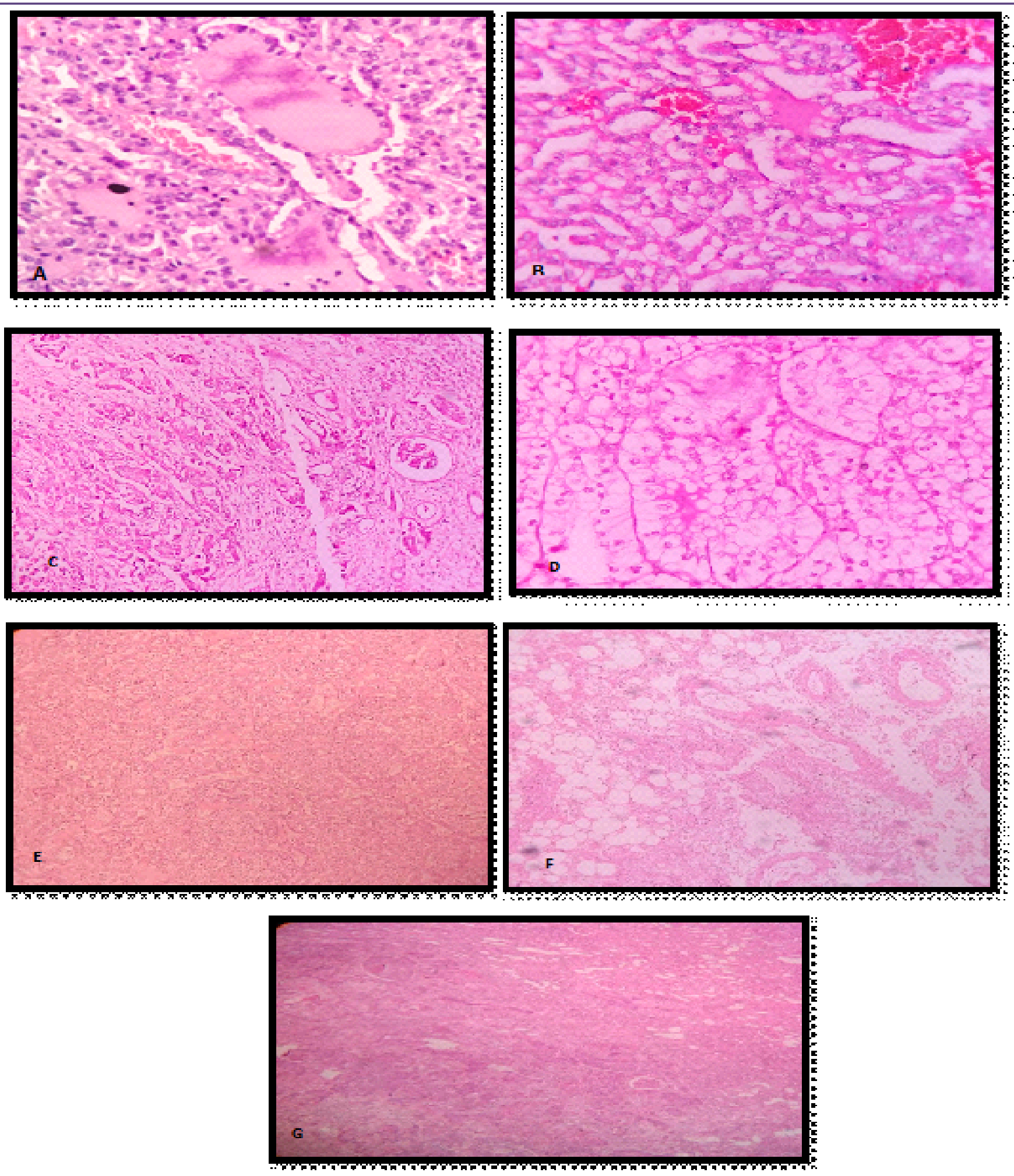

Fig. 2. A. Thyroid follicular carcinoma like renal cell carcinoma. B. Tubular mucinous variant of renal cell carcinoma. C. Chromophobe variant of RCC. D. Clear cell variant of RCC. E. Renal Oncocytoma. F. Angiomyolipoma. G. Squamous cell carcinoma of kidney. 
et al, where the most common age group affected was $5^{\text {th }}$ and $6^{\text {th }}$ decade. ${ }^{[5,9]}$ This study is also variable with Vinay KS et al, Ajay Kumar et al and Kotta Devender Reddy et al studies, where most common age group affected was $4^{\text {th }}$ decade.$^{[3,10,11]}$ In our study, the mean age of the population was $39 \pm 5.87$ years. Study by Jaynul Islam et al., shows that the most common affected age group was 21-30 years, it is quite similar to Habib et al., and Mohammad et al. ${ }^{[12-14]}$ Whereas, in a study by Pankaj Beniwal et al., the mean age was $64.02 \pm 7.87$ years; $67.7 \pm 6.4$ years in Gupta et al.; and $63.5 \pm 3.2$ years in Kohli et al. study. ${ }^{[15,16]}$

In the present study, 48 cases were males and 22 cases were females showing male preponderance. This is in concordance with Baswaraj et al, Mohammad Rafique et al., and Kishore H Suryawanshi et al. ${ }^{[8,17,18]}$

In a study by, Vikram Narang et al., encountered male preponderance with a M:F ratio of $1.7: 1$ which was also noted by Neggada et al., (1.6:1) and Eke $\mathrm{N}$ et al., (1.6:1). [17-20]

In a study by Pankaj Beniwal et al., males accounted for $70.4 \%(n=162)$ of the study population. Nephrotic syndrome (NS) is the most common $(57.02 \%)$ clinical presentation, followed by nephritic syndrome (33.19\%) which was quite closer to the study of Jalalah at Saudi Arabia and Mardanpour et al at Iran. ${ }^{[21,22]}$

Among the adequate biopsies, 95.19\% were glomerular diseases, $3.37 \%$ were tubulointerstitial nephritis and $1.44 \%$ were ATN. Study at CMC, Velor and China shows above frequency and Pakistan reveals the very high incidence of TIN (11.6\%). Mohammad et al., got 3\% ATN among 100 renal biopsies in Pakistan. ${ }^{[23-25]}$

Out study results shows discrete spectrum of renal lesions. Study by Vikram Narang et al., shows that there were 82 cases renal tumours; out of which $70(85.3 \%)$ cases were of renal cell carcinoma followed by transitional cell carcinoma 7 cases (8.5\%). Beisland et al., who had $72.7 \%$ cases of RCC and $21.9 \%$ cases of TCC Jha et al., had $87.3 \%$ cases of RCC and $12.6 \%$ cases of T.C.C. while Ali Tebibi et al., encountered $84.6 \%$ cases of RCC and $4.7 \%$ cases of TCC. ${ }^{[26-28]}$ Low grade RCC (nuclear grade 1 and 2) comprised of $63.1 \%$ case while high grade RCC (nuclear grade 3 and 4 ) comprised of $36.9 \%$ cases and Srivastava et al., also had $52.8 \%$ low grade tumours. ${ }^{28,29]}$

In the present study, among neoplastic lesions, majority were malignant $(69.72 \%)$. This is in concordance with Vinay KS et $\mathrm{al}^{3}$, Bharti Devi Thaker et $\mathrm{al}^{31}$ studies. In the present study, non-neoplastic lesions $(81.4 \%)$ were predominant over neoplastic lesions (18.6\%). Studies conducted by Bersland et al., shows 30.8\% non-neoplastic and Danenport et al., shows $48.6 \%$ non-neoplastic. ${ }^{[32,33]}$

In a study by Vikram Narang et al. shows the total of 155 total nephrectomy specimens, out of which 82 cases were neoplastic and 73 cases with chronic pyelonephritis(60.3\%). Renal neoplasms constituted 82 cases. Clear cell RCC was the commonest $(57$ cases) followed by transitional cell carcinoma of renal pelvis ( 7 cases).

In the present study, among non-neoplastis lesions, chronic pyelonephritis with hydronephrosis was predominant. This is in concordance with Shanmuga Swamy et $\mathrm{al}^{5}$ and Ashima N Amin et al studies. ${ }^{[33]}$ In a study by Bharti Devi Thaker et al., ${ }^{31}$ showed that maximum number of cases were of Non neoplastic. Non Neoplastic (62 cases) were the most common followed by malignant cases ( 7 cases) and the least common were benign tumours ( 1 case). ${ }^{[34,35]}$

\section{Conclusion}

The present study reveals various histological patterns of lesions in renal biopsies and nephrectomy specimens. Our study reveals that non-neoplastic lesions are more commonly encoutered lesions. Most common age group affected was $3^{\text {rd }}$ and $4^{\text {th }}$ decade. Chronic pyelonephritis is the most common non-neoplastic lesion and Chromophobe renal cell carcinoma being common among malignant tumors. Benign tumors of kidneys are less common.

\section{References}

1. Kumar MR, Meghana P, Vasudev V, Bharathi M. Histopathological spectrum of renal tumors in nephrectomy specimens. Indian J Pathol Oncol 2019;6(1):52-56.

2. Monalisa $\mathrm{H}$ et al. Histopathological spectrum of pediatric nephrectomies. Indian Journal of Pathology and Microbiology, 2010; 53(1):101-102.

3. Vinay KS, Sujatha S. Histopathological Spectrum of Nephrectomy Specimens: Single Center Experience. Biomed J Sci\&Tech Res 6(3)- 2018. BJSTR. MS.ID.001350.

4. Aiman A, Singh K, Yasir M. Histopathological spectrum of lesions in nephrectomy specimens: A five-year experience in a tertiary care hospital. J SciSoc 2013;40:148-54.

5. Shanmugasamy K, Anandrajvaithy, Venkatraman K, Dhananjay S Kotasthane. Histopathological spectrum of nephrectomy specimen in a tertiary care centre: with an emphasis on chronic pyelonephritis. Ann Path Lab Med 2017;4(5): 573-578.

6. Ray R, Mahapatra R, Khullar S, Pal D, Kundu A. Clinical characteristics of renal cell carcinoma: Five years review from a tertiary hospital in Eastern India. Indian $J$ Cancer. 2016;53(1):114-17.

7. Muhammad A, Khan K, Rana S. Nephrectomy- an overview, Pak J Surj,2012, 28(2):102-105. 
8. Kishor H. Suryawanshi1, Rajshri P. Damle - Annals of Pathology and Laboratory Medicine, 2017; 4,

9. Swarnlatha A, Rohit A. Histopathological spectrum of lesions in nephrectomies- A five year study. Int J Sci Res 2017;6(7): 44-46.

10. Ajay K. A histopathological study of non neoplastic lesions in nephrectomy specimens. Int $J$ Med H Res 2017: 3(2): 137-138.

11. Reddy KD, Gollapalli SL, Chougani S, Shivalalitha Sidagam, Amanulla khan Mohmmed, et al. A clinic-morphological spectrum of nephrectomy specimens-an experience from a tertiary care hospital. Int J Health Sci Res 2016;6(11): 67-72.

12. Islam SJ, Haque WS, Akhter S, Mahbubul Alam S M. Histomorphological pattern of renal biopsy in Dhaka: A single center study. Saudi J Kidney Dis Transpl 2018;29:1159-64

13. Mohammad N, Khan TM, Orakzai AN, Imran M. Histological pattern of glomerulopathies. Gomal J Med Sci 2012;10:7-11.

14. Habib MA, Badruddoza SM. Pattern of glomerular diseases among adults in Rajshahi, the Northern region of Bangladesh. Saudi J Kidney Dis Transpl 2012;23:876-80.

15. Beniwal P, Singh SK, Malhotra V, Agarwal D, Sharma M, Joshi P, Khandelwal S, Gaur N, Sharma S. Gerontolizing nephrology: Spectrum of histopathological findings of kidney biopsy in the elderly. Indian J Nephrol[Ahead of print publication].

16. Kohli HS, Jairam A, Bhat A, Sud K, Jha V, Gupta KL, et al. Safety of kidney biopsy in elderly: A prospective study. Int Urol Nephrol 2006;38:815-20.

17. Narang VI, Garg BH, Walia AS, Sood NE, Malhotra VI. Histomorphological Spectrum of Nephrectomy Specimens-A Tertairy Care Centre Experience. National Journal of Laboratory Medicine. 2016 Apr;5(2):51-4.

18. Ghalyini IF. Pathological spectrum of nephrectomies in a general hospital. Asian J Surg. 2002;25 (2):163-69.

19. Nggada HA, Eni UE, Nwankuro EA. Histopathological finding in nephrectomy specimens. A review of 42 cases. Niger Postgrad Med. J. 2006; 13(3):244-46.

20. Eke N, Echen RC, Nephrectomy at the university of part Harconsist Teaching Hospital; a ten year experience. Afer J Med Sci. 2003; 32(2):173-77.

21. Jalalah SM. Patterns of primary glomerular diseases among adults in the western region of Saudi Arabia. Saudi J Kidney Dis Transpl 2009;20:295-9.
22. Mardanpour K, Rahbar M. Histopathologic patterns of adult renal disease in Kermanshah, Iran: A 6-year review of two referral centers. Caspian J Intern Med 2013;4:717-21.

23. Balakrishnan N, John GT, Korula A. Spectrum of biopsy proven renal disease and changing trends at a tropical tertiary care centre 1990-2001. Indian J Nephrol 2003;13:29-35.

24. Li LS, Liu ZH. Epidemiologic data of renal diseases from a single unit in China: Analysis based on 13,519 renal biopsies. Kidney Int 2004;66:920-3.

25. Mubarak M, Kazi JI, Naqvi R, et al. Pattern of renal diseases observed in native renal biopsies in adults in a single centre in Pakistan. Nephrology (Carlton) 2011;16:87-92.

26. Beisland C, Medley PC, Sander S. Nephrectomy indications complications and postoperative mortality in 646 consecutive patients. Eur Urol. 2000; 37: 58-64.

27. Tabibi A, Parvin M, Abdi H, Bashtar R, Zamani N. Correlation between size of renal cell carcinoma and its grade, stage and histological subtype. Urol J. 2008; 4: 10-13.

28. Fuhrman SA, Lasky LC, Limas C. Prognostic Significance of Morphological parameters in renal cell carcinoma. Am J Surg Path. 1982; 6: 655-63.

29. Srivastava A, Mandhani A, Kapoor R, Jain M, Dubey D, Raghavendra MA et al. Prognostic factors in patients with renal cell carcinoma: Is TNM (1997) staging relevant in Indian subpopulation. Indian J Cancer. 2004; 41:99-103

30. Jha MS, Gupta N, Agrawal S, Ansari MS, Dubey D Mandhani A et al. Single centre experience of laproscopic nephrectomy: impact of learning curve on outcome. Indian J Urol. 2007;23 (3):253-56

31. Bharti DT, Kailash S (2017) A histopathological review of Nephrectomy specimens Received in a Tertiary care hospital-A retrospective study. $\mathrm{J} \mathrm{Med} \mathrm{Sci} \mathrm{Cl}$ Res 5(6): 23807-23810.

32. Davenport K, Temoney AG, Reeley FX: A 3 year review of British association of urological surgeons sections of endourology laproscopic nephrectomy audit. BJ U Int. 2005; 97: 333-37.

33. Ashima NA, Pushpalatha P, Krishnaraj U (2015) A Histopathological spectrum of nephrectomy specimens in a tertiary hospital in southern India. Int J Biol Med Research. 6(3): 5173-5178.

34. Beisland C, Medley PC, Sander S. Nephrectomy indications complications and postoperative mortality in 646 consecutive patients. Eur Urol. 2000; 37: 58-64.

35. Mannan R, Kaur H, Singh PA et al. A Histopathological spectrum of Renal lesions : A 3 year prospective study of a Tertiary care teaching centre. Int J Dent Med Res 2015;1(6): 11-13.

*Corresponding author:

Dr Shilpa Karamchedu, Assistant Professor, Department of Pathology, SVS Medical college, Yenugonda, Mahabubnagar, Telangana-509002, India.

Phone: +91 9949911055

Email: suresh_harithasa@yahoo.com

Date of Submission : 09/01/2020

Date of Acceptance : 17/06/2020

Financial or other Competing Interests: None.

Date of Publication : 30/08/2020 